\title{
More than what was asked for: company specific competence programs as innovation hothouses
}

\author{
Hanne O. Finnestrand ${ }^{1}$, Kristoffer Magerøy ${ }^{1}$ and Johan E. Ravn ${ }^{1}$ \\ ${ }^{1}$ SINTEF Technology and Society, Industrial Management, Trondheim, Norway \\ \{hanne.o.finnestrand, kristoffer.mageroy, \\ johan.e.ravn\} @sintef.no
}

\begin{abstract}
The development of a company towards high-quality products and services demands higher skills among employees. Furthermore, companies providing extensive training are more likely to be productive and innovative. The question explored in this paper is how the demand for flexibility and high innovation rates in high-tech companies affects the choice of "making or buying" necessary skills. In order to study this, we have made use of organizational theory supported by empirical findings in two Norwegian companies experiencing the need for being flexible and facing challenges regarding increasing innovation pressure. Through our industry insights and specifically the case studies presented, we are led to conclude that in-house training programs contribute to build important prerequisites for flexible organizations with capability to innovate and change.
\end{abstract}

Keywords: in-house training, company specific competence programs, employee skills, vocational workers, flexible and innovative companies, case study

\section{Introduction}

Research indicates that most Western countries with a skilled and educated but highcost work force are moving towards high-tech manufacturing industries [1]. Consumers demand a broader range of high quality products and services and there are continuing developments in ICT that can enable more flexible manufacturing systems. Danford et al. [2] and White et al. [3] hold that the interest for highly qualified and flexible workers can be understood as a response to changes in the market and technological conditions. For instance, when studying the automobile industry, MacDuffie [4] found that companies that want to adapt a more flexible form of automobile assembly require more highly skilled workers. These are workers with the knowledge and ability to undertake the problem solving implied by this mode of production.

In addition to vocational training at school or as apprenticeship, most workers acquire their job skills at the work place as in-house training or in training offered by externals [5]. However, the factors that are related to such workplace rewards as employment stability, income, and occupational status also predict access to training opportunities. This means that highly educated workers participate more often than less educated workers such as vocational workers in workplace training, and workers in higher status occupations are more likely to receive training than workers in more 
marginal positions [6,7]. Also when it comes to workplace training, vocational workers are not prioritised. Bills and Hudson [5] observed enormous differences in training rates across occupations. Upper level workers, like managers and professionals, participate in training at far higher rates than less well-positioned workers do.

Furthermore, people who work with customers and products often know more about the way the organization operates than people in staff and senior management positions. Shop floor workers may therefore be in a better position to make suggestions and develop innovations than others. Knowing that companies in advanced manufacturing are dependent on a production system that adapts and changes fast according to the demands in the market, such companies should therefore see the need for a highly qualified work force that is involved in and informed about the company's value creating activities - and with the necessary skills to both produce and adapt when necessary. Altogether, the need for highly skilled vocational workers is high and even increasing as advanced manufacturing develops further into flexible customer-centric organizations. When making an effort in acquiring those workers, companies can either choose to "buy" a skilled workforce by careful and selective hiring, or "make" a skilled workforce by the provision of training [8]. The question explored in this paper is how the demand for flexibility and high innovation rates in high-tech companies affects the choice of "make or buy". In order to study this, we have made use of organizational theory supported by empirical findings in two Norwegian companies experiencing the need of being flexible and facing challenges regarding increasing innovation pressure. One of the companies is a manufacturing company developing and producing specialized products, while the other is a yard delivering steel constructions to the off-shore oil and gas industry.

\section{Development of skills}

Organizational researchers have claimed that skills inside a company are key to success. In a world where access to information is fast and widespread, those organizations who can create and use their own knowledge are likely to be able to build and sustain competitive advantage [9, p.6]. From the "make or buy" perspective, there is evidence that employers gain from providing or supporting training, just as employees gain from participating in it. Companies that provide extensive training are more likely to be productive, innovative, and competitive [5]. Also, research on situated learning has demonstrated the benefit of utilizing authentic contexts [10], where the operators can simulate a scenario and learn based on both realistic and relevant situations on the job to increase their understanding of the interplay between tools, techniques and environment.

A manufacturing company that starts developing high-quality products and services must increase its response and innovation rate. To do so, it has to abandon the tight control-oriented approach and rely on workforce agility and responsibility. This requires higher skills and other kinds of skills among the employees. Boxall and Purcell [11] argue that there are major differences in what is invested in employees between high-tech manufacturing companies, on the one hand, and labour-intensive, low-tech manufacturing industry on the other. Companies can profit from teaching operators to solve technical problems as they occur, instead of calling in specialist 
technicians for problem solving and delaying the production [12]. Because companies rely on skilled workers in high-tech manufacturing, workplace practices centred on employee participation are assumed to pay off. This does not directly mean that inhouse training programs can facilitate and contribute to a more flexible and innovative organization. However, Bessant [9] found that high involvement workplace practices encourage innovation, change and problem-solving activities on the shop floor, it involves more people in the process and by this create more opportunity for innovations to be developed. As in-house training creates new meeting arenas and often put focus at internal processes and procedures, as well as facilitates professional discussion, it is assumable that it leads to higher involvement workplace practices. And, hence, cause innovation opportunities.

\section{Methodology}

An instrumental case study approach is adopted. We have carried out case studies in two different companies as evidence from multiple cases is generally considered more compelling than a single case study [13]. An instrumental case study provides insight into a particular issue, redraw generalizations, or build theory [14]. As with most instrumental case studies, the research team wanted to create a new theory by building on and testing existing theory. Findings from the empirical investigation are compared with literature to bring further detail and structure to current issues. Data is collected through workshops, semi-structured interviews and meetings with representatives of the case companies.

\section{Case studies}

The presentation of each case study starts with a short introduction to the company, followed by a summary of the most relevant findings. In order to anonymize the companies, we have named them company A and company B.

\section{Company A}

Company A develops and produces power distribution systems for oil and gas installations and is given a lead development role within the global corporate. The centre counts 200 permanent employees, educationally dispersed between unskilled workers, vocational workers, engineers, masters and PhDs. In addition to this comes around 40 consultants and temporary employees. Reduced appreciation of the profession and recruitment problems are considered some of the company's biggest future threats. The company has gone from traditional batch production to more unique and complex one-of-a-kind products designed in collaboration with customers. This change implied other kinds of skills on the shop floor as well as in engineering. A typical project may consist of approximately 4,000 assembly hours and 2,500 engineering hours [15]. Introduction of more advanced manufacturing, with customized products, flexible automation and computer aided manufacturing imply that the work systems become more technologically complex. This increasing complexity puts increased demands on 
workers' skills and knowledge. Supplementing manual skills and tacit knowledge, workers also are required to perform tasks like machine set-up and programming, which used to be reserved for technicians and engineers [16].

There is also a qualitative change in the necessary repertoire of skills. Besides professional or technical skills, there is an increased need of communication and social skills. Because the products are developed in collaboration with the customers in order to fit the customers' exact needs, the products end up as unique with their unique work plan. This means that the engineers seldom were able to submit fixed work plans to the shop floor that were ready to be used. The skilled workers on the shop floor often saw that they had to make adjustments to the work plans in order to make them practical. The practical skills of the shop floor workers ended up as very important in this kind of production and the division between blue-collar work tasks and engineering tasks was in other words blurred [15]. Thus, distinct technical competences and skills must be accompanied by broader competencies and skills, like learn to learn, critical problem solving, cultural awareness, collaboration and communication.

To avoid lay-offs but remain flexible, company A has chosen to utilize a certain amount of temporary workers. However, this increases the demand for internal teaching, and if the percentage of temporary workers passes somewhere between 10-20\%, then they experience a drop in productivity. Still with lower percentages of temporary workers, the training of them takes valuable focus from apprentices and their learning process. The trend of increased turnover has the same effect, as it demands more training of newly-hired employees. Altogether, the wear and tear at senior vocational workers who continuously remain in a teaching situation can exceed the rational boundaries. This can potentially result in lack of motivation, absent of time to selfdevelopment and limited possibility to contribute to continuous improvement efforts. Avoiding such a trend is important, as a strong professional culture is considered key to maintain a powerful innovative environment.

Combining the recruitment challenge, usage of temporary workers, higher turnover, increased complexity, growing demand of workers' skills and knowledge, as well as the enhanced need of communicational and social skills, this has led the company to realize that they need to develop an overall strategy for in-house training. They acknowledge the need to prioritize more time and resources to educational purposes and the strategy will treat training of senior vocational workers as well as apprentices and temporary employees. They realize that as the company has evolved from batch production to complex one-of-kind products, the possibility to hire sufficient-skilled vocational workers has been reduced and they have to develop required skills themselves. As the personnel safety representative puts is: "Mass production is out of the question, so we can't buy our way to competence."

\section{Company B}

Company B delivers large steel constructions for use on oil and gas offshore platforms and onshore process plants. The deliverables are described as projects and take years to complete. Usually, the company employs about 500-600 employees but the exact number of employees varies due to the market situation, which can change quite 
drastically over just two to three years. This means that company B has for several years been through many periods characterized by temporary redundancies, lay-offs, very short duration of the contracts, and a constant threat of close downs just to be followed by very high activity and even too much work in periods. In 1999/2000 there was a huge crisis in the Norwegian offshore industry which left company B in an unusually difficult situation. For more than a year the company had no deliveries which meant that the company had to lay-off the entire work force - some of them temporary, and as much as 400 employees permanently. The management and the union worried that the company would lose important competencies when laying off that many employees and decided to carry out an outstanding effort in skill development among the employees. They aimed on new contracts and the skill development program was done in order to qualify the company for new contracts.

The management emphasized in particular three arguments for carrying out a skill development program. Firstly, the difficult situation demanded other kind of competencies than the company used to offer. In order to utilize new markets, the employees also needed to turn their skills in new directions. Secondly, the management claimed that the employees needed not only new skills, but also more skills. Thirdly, in order to be more flexible and take on different projects, operators were encouraged to take more than one certificate of apprenticeship.

The union supported the management's project on saving the company through development of skills. They argued that knowledge within one work task such as welding was very helpful, for example when scaffolding. A welder doesn't only build in accordance to what he or she has learned, but actually how he or she would have liked it to be if they were to do the welder job. In other words, they argued for getting ready for a greater understanding of the entire work process.

The shop stewards also argue that workers with several certificates of apprenticeship or formal skills are in a better position to keep their jobs in difficult periods. Although there is no job in their own local company, there may be temporary jobs within the company group. And in these situations, a broader spectrum of skills increases the possibilities for a temporary job other places. One of the shop stewards pointed out, "If people are interested in traveling - there is always work."

To develop certain workers' skills turns out to be a shop union strategy in getting ready for workforce reductions after the union format:

"We have said that in relation to workforce reduction, the seniority principle is still the most important argument. However, we see that skills are increasingly more important and there is more and more focus on the right skills when we have to cut the workforce. That's the reason why we want to participate and interfere in the discussion about who is to be offered education and courses. Otherwise, some managers may say that, "I want you here for a long time - I will offer you this and that in order for you to stay here longer." I don't know whether we have been good at it, but we have at least tried to offer this" (shop steward, company B).

The company chose to focus on five areas when up-skilling the employees: multidisciplinarity, use of ICT, and particular expertise in logistics, management development, and team development. The skill development program lasted for almost two years and most of it was financed through public funding. When the program ended, 
the employees had all together carried out more than 50000 day's work on skill development. Almost all training had been in-house training in collaboration with local colleges.

In retrospect the HR-manager claims that the difficult situation the company experienced in 2000 have left them with very useful experiences of the importance of a skill development program that not only make ready for necessary competence, but also enables employees to understand what kind of competence they need and how to acquire this competence. The HR-manager now reports that employees have started to demand more training, employees are taking responsibility for their own skill development, and vocational workers require training on areas they would never require earlier, like courses within engineering, coaching, logistics, and administration.

\section{Discussion and conclusion}

From a human resource perspective, training and education are often funded in two aspects; the need for offering attractive work places and keeping employees motivated; and second, the need for continuously maintaining and developing the company's knowledge base. Neither the findings from company A nor company B are contradictory to this; however, they contain some elements that draw a wider picture of the motivation behind and the impact caused by on-the-job training.

As presented in the introduction, the development of a company towards highquality products and services demands higher skills among employees. Furthermore, companies providing more training are more likely to be productive and innovative. However, why should companies facing high demands of flexibility and innovativeness put more effort into establishing company specific competence programs? What make them differ from high-tech mass production companies and why can't they buy external training programs or hire high-skilled workers? Research on situated learning has demonstrated that in-house learning increases the understanding of the interplay between tools, techniques and environment, but this does not cover the different needs companies that rely on flexibility are facing, compared with more stable companies. However, through our industry insights and specifically the case studies presented, we believe that an in-house training program contributes to build some important prerequisites for flexible organizations with capabilities to innovate and change.

Firstly, a company specific competence program provides a structure and a system capable of effectuating changes faster. It is also likely, that persons dedicated to the competence program are better skilled to develop new procedures and the following sharing of new practice. The increased understanding of entire work processes after the extensive training in company B support this as a possible enabler.

Secondly, a more highly skilled and innovative workforce are found key to flexible organizations. Company A has experienced that the evolution to batch and one-of-akind production has put pressure on internal training programs. They also pinpoint that innovativeness is determinant on a strong professional focus, which is likely to be increased by structured training. But also the increasing challenges of hiring highly skilled workers support the need for in-house training. 
Thirdly and finally, a more applicable workforce increases flexibility. As seen in company B, a broader set of skills can increase the possibility to take temporary jobs at other locations within the corporate or within neighbouring companies in industrial clusters. For organizations exposed of large fluctuations, such opportunities can be key to maintain competence in the area through periods of lay-offs.

Altogether this result in the following proposition: Company specific competence programs contribute at building dynamic and flexible organizations and increase their capability to face change in technology and marked. Future research should investigate this further, including each of the prerequisites proposed and their cause-effect relations.

This work has been conducted with support from the project Verdikjede fagarbeider supported by The Regional Research Counsil of Mid-Norway and the research project HPWS.no supported by The Research Council of Norway.

\section{$5 \quad$ References}

1. Ashton DN, Sung J (2002) Supporting workplace learning for high performance working. International Labour Organization,

2. Danford A, Richardson M, Stewart P, Tailby S, Upchurch M (2008) Partnership, high performance work systems and quality of working life. New Technology, Work and Employment 23 (3)

3. White M, Hill S, Mills C, Smeaton D (2004) Managing to Change? British Workplaces and the Future of Work. Palgrave Macmillan, Basingstoke

4. MacDuffie JP (1995) Human resource bundles and manufacturing performance: Organizational logic and flexible production systems in the world auto industry. Industrial and Labor Relations Review 48:197-221

5. Bills DB, Hodson R (2007) Worker training: A review, critique, and extension. Research in Social Stratification and Mobility 25 (4):258-272

6. Frazis H, Gittleman M, Joyce M (2000) Correlates of Training: An Analysis Using Both Employer and Employee Characteristics. Industrial and Labor Relations Review 53 (3):443-462

7. Arulampalam W, Booth AL, Bryan ML (2003) Training in Europe, IZA Discussion paper series, NO. 933.

8. Knoke D, Janowiec-Kurle L (1999) Make or buy? The externalization of company job training. Research in the Sociology of Organizations 16:85-106

9. Bessant J (2003) High-involvement innovation : building and sustaining competitive advantage through continuous change. Wiley, Chichester

10. Lave J, Wenger E (1991) Situated learning: Legitimate peripheral participation. Cambridge university press,

11. Boxall P, Purcell J (2010) An HRM perspective on employee participation. In: Wilkinson A, Gollan PJ, Marchington M, Lewin D (eds) The Oxford handbook of participation in organizations. Oxford University Press, Oxford, pp XV, 624 s. 
12. Wall TD, Corbett JM, Clegg CW, Jackson PR, Martin R (1990) Advanced manufacturing technology and work design: Towards a theoretical framework. Journal of Organizational Behavior 11 (3):201-219

13. Yin RK (2009) Case study research: Design and methods. Sage publications, 14. Stake RE (2006) Multiple Case Study Analysis. The Guilford Press, New York 15. Finnestrand HO, Ravn JE (2007) Prosjektindustri - partssamarbeid og nye organisasjonsformer. In: Brøgger B (ed) A tjene på samarbeid : medvirkning, partssamarbeid, bedriftsutvikling. Gyldendal akademisk, Oslo, p $173 \mathrm{~s}$.

16. Knutstad G, Ravn JE Technology Utilization as Competitive Advantage-A Sociotechnical Approach to High Performance Work Systems. In: Advanced Materials Research, 2014. Trans Tech Publ, pp 555-561 